Ekonomica Sharia: Jurnal Pemikiran dan Pengembangan Ekonomi Syariah Volume 6 Nomor 1 Edisi Agustus $2020 \mid 33$

\title{
ANALISIS TINJAUAN HUKUM ISLAM TERHADAP PEDAGANG PAKAIAN DALAM PENETAPAN HARGA DI PASAR DEMPO PERMAI KOTA PAGAR ALAM
}

\author{
${ }^{1}$ M. Agus Maryanto, ${ }^{2}$ Reni Hariani, ${ }^{3}$ Deva Mardalena \\ ${ }^{1}$ Sekolah Tinggi Ekonomi Dan Bisnis Islam Kota Pagaralam. Email: magusmrynto@gmail.com \\ ${ }^{2}$ Sekolah Tinggi Ekonomi Dan Bisnis Islam Kota Pagaralam. Email: ren6803@ gmail.com \\ ${ }^{3}$ Sekolah Tinggi Ekonomi Dan Bisnis Islam Kota Pagaralam. \\ Email: devamardalena@gmail.com
}

\begin{abstract}
This research aims at asmaterial input for using the systemthe determination of the price of clothing, materials considerations for sellers in pricing according to principles of Islamic lawmaka in the current study, the researchers want to do an analysis of the review of the price of the clothes in the apply in the market based on the Islamic law Scenic Dempo in order not to violate the provisions of Sharia. In this thesis are described and analyzed pricing of clothes made by traders of clothing in the market town of Picturesque Natural Fence Dempo. The research method used is descriptive qualitative methods, i.e., explain, describe, and illustrate the situation, and then analyzed and drawn conclusions. Data collection techniques used by researchers is the observation, documentation and interviews. Based on the results of the analysis, it can be inferred that the traders of clothing in the market town of Picturesque Natural Fence Dempo method using cost-based pricing, and using principles of trade in Islam. Then the pricing practised by traders of clothing in the market town of Picturesque Natural Fence Dempo is in compliance with Islamic law, the profits obtained also according to Islamic law because the benefits of the advantage to the passing of their efforts
\end{abstract}

Keywords: Pricing, Islamic Law.

\begin{abstract}
Abstrak
Penelitian ini bertujuan sebagai bahan masukan untuk menggunakan sistem penetapan harga pakaian dan bahan pertimbangan bagi penjual dalam penetapan harga sesuai prinsip Hukum Islammaka di dalam penelitian ini, peneliti ingin melakukan analisis tinjauan terhadap harga pakaian yang di terapkan di pasar Dempo Permai berdasarkan Hukum Islam agar tidak melanggar ketentuan syariah. Dalam skripsi ini dijelaskan dan dianalisis penetapan harga pakaian yang dilakukan oleh pedagang pakaian di pasar Dempo Permai kota Pagar Alam. Metode penelitian yang digunakan adalah metode deskriptif kualitatif, yaitu menjelaskan, menjabarkan, dan menggambarkan situasi yang ada, kemudian dianalisis dan ditarik kesimpulan. Teknik pengumpulan data yang digunakan oleh peneliti adalah observasi, dokumentasi dan wawancara. Berdasarkan hasil analisis, maka dapat disimpulkan bahwa pedagang pakaian di pasar Dempo Permai Kota Pagar Alam menggunakan metode penetapan harga berbasis biaya, dan mengunakan prinsip berdagang dalam Islam. Maka penetapan harga yang diberlakukan oleh pedagang pakaian di pasar Dempo Permai Kota Pagar Alam sudah sesuai dengan hukum Islam, keuntungan yang diperoleh juga sesuai dengan hukum Islam karena manfaat dari keuntungan tersebut untuk berjalannya usaha mereka.
\end{abstract}

Kata Kunci: Penetapan harga, Hukum Islam 
34 | M. Agus Maryanto, et.al, Analisis Tinjauan Hukum Islam Terhadap Pedagang....

\section{DASAR PEMIKIRAN}

Allah SWT menciptakan manusia dan menjadikan makhluk yang membutuhkan makanan, minuman, pakaian dan tempat tinggal. Sejak awal sejarah manusia, orang bekerja keras dalam kehidupan untuk memenuhi terjaminnya barang dan jasa, dan memanfaatkan nikmat-nikmat yang Allah SWT akan berikan bagi mereka. Ketika tidak sanggup seorang diri dalam memenuhi segala kebutuhan barang dan jasa, terjadilah kerjasama antar manusia dalam rangka menjamin terpenuhnya kebutuhan-kebutuhan itu.

Islam sebagai agama Allah SWT, mengatur kehidupan manusia baik kehidupan di dunia maupun akhirat. Perekonomian adalah bagian dari kehidupan manusia, maka tentulah hal ini ada dalam sumber yang mutlak yaitu Al-Qur'an dan As-Sunnah, yang menjadi panduan dalam menjalin kehidupan. Kedudukan sumber yang mutlak ini menjadikan Islam sebagai suatu agama yang istimewa dibandingkan dengan agama lain sehingga dalam membahas perspektif ekonomi Islam segalanya bermuara pada hokum Islam berdasarkan Al-Qur'an al Karim dan As-Sunnah Nabawiyah (Huda, 2008: 3, Aravik, 2016: 7).

Islam telah mengatur mengenai cara bermuamalah bagi seorang muslim. Dalam jual beli kaitannya dengan penetuan harga, Islam meperbolehkan jual beli dan melarang riba. Hal tersebuat tertuang dalam surat Al-Baqarah: 275

Artinya: Orang-orang yang memakan (harta) riba, tiada berdiri melaikan seperti berdirinya orang yang dibantingkan syetan karena gila. Demikian itu karena mereka berkata: Jual beli itu hanya seperti riba. Allah SWT menghalalkan berjual-beli dan mengharamkan riba. Maka siapa yang menerima pengajaran dari Tuhan-Nya, lalu berhenti (melakukan riba), maka untuknya pa yang telah terlalu dan urusannya terserah kepada Allah SWT. Barang siapa kembali (melakukan riba), mereka itulah penghuni neraka, serta kekal didalamnya (Kementerian Agama, 1938: 63).

Untuk lebih menegaskan lagi yang berkenaan dengan ayat di atas, maka maksud dari ayat tersebut adalah Allah SWT menegaskan bahwa telah dihalalkan jual beli dan di haramkan riba. Orang-orang yang membolehkan riba dapat ditafsirkan sebagai pembantahan hukum-hukum yang telah di tetapkan oleh Allah SWT yang maha mengetahui lagi maha bijaksana. Riba yang dahulu telah dimakan sebelum turunnya 
Ekonomica Sharia: Jurnal Pemikiran dan Pengembangan Ekonomi Syariah Volume 6 Nomor 1 Edisi Agustus 2020 | 35

firman Allah SWT ini, apalagi pelakunya bertobat, tidak ada kewajiban untuk mengembalikannya dan dimaafkan oleh Allah SWT. Sedangkan bagi siapa saja yang kembali lagi kepada riba setelah menerima larangan Allah SWT, maka mereka adalah penghui neraka dan kekal di dalamnya (http://banksyariahindo.wordpress.com/2011/10/23/tafsir-al-baqarah-ayat-275/, diakses pada tanggal 06 April 2019, Pukul 19:43 WIB).

Penetapan harga adalah harga yang diperoleh dari interaksi antara kekuatan permintaan dan penawaran dalam suatu persaingan sempurna, penetapan harga merupakan strategi kedua dilakukan setelah strategi pemasaran dilakukan, penetapan harga bukan suatu hal yang mudah untuk dilakukan karena keputusan tersebut akan mempengaruhi penjualan dan keuntungan (Kamalia, 2011: 5).

Biasanya, pembodohan banyak terjadi ketika konsumen kurang perhatian terhadap harga pasar atau kurang perhatian melihat situasi barang, memang harga dalam jual beli mengikuti laju perekonomian masyarakat, seperti faktor permintaan dan penawaran barang. Namun para pedagang hendaknya tetap memperhatikan kode etik pembisnis muslim, dalam arti tidak bernafsu meraup keuntungan dengan terlalu semangat memanfaatkan kesempatan. Karena ini yang memicu tindakan ghabn (pembodohan). Etika bisnis yang dipraktikkan Rasulullah SAW adalah bersikap jujur, amanah, tepat dalam menimbang, menjauhi gharar, tidak menimbun barang, tidak melakukan al-ghab dan tadlis, dan saling menguntungkan antara penjual dan pembeli (Saifullah, 2011: 154, Zamzam dan Aravik, 2020: 5).

Rasulullah SAW menyatakan bahwa harga dipasar itu di tentukan oleh Allah SWT. Berarti bahwa harga di pasar tidak boleh di intervensi oleh siapapun. Adapun hadist Rasulullah SAW, yang berkaitan dengan penetapan harga adalah suatu riwayat dari Anas bin Malik

Pada zaman Rasulullah SAW terjadi lonjakan harga dipasar, lalu sekelompok orang menghadap Rasulullah SAW seraya mereka berkata, "Ya Rasulullah SAW telah terjadi kenaikan harga-harga barang makan tetapkan harga untuk barang-barang tersebut. Rasulullah SAW menjawab: Sesungguhnya Allah SWT yang maha penetap harga, yang menyempitkan dan melapangkan serta memberi rezeki, saya berharap akan bertemu 
36 | M. Agus Maryanto, et.al, Analisis Tinjauan Hukum Islam Terhadap Pedagang....

dengan Allah SWT dan tidak seorangpun yang menuntut saya karena kedzaliman yang saya lakukan dalam masalah darah dan harta (Rozalinda, 2017: 162).

Perdagangan tidak akan pernah lepas dengan yang namanya pasar. Pasar rentan dengan kecurangan dan juga perbuatan ketidak adilan yang mendzalimi pihak lain, karena peran pasar penting dan juga rentan dengan hal- hal yang dzalim, maka pasar tidak terlepas dengan sejumlah aturan syariat, yang antara lain terkait dengan pembentukan harga dan terjadinya transaksi di pasar (Aseng Yopinbeska, http://www.scribd.com/document/367759210/Makalah-Ekonomi- Islam-Konsep-PasarDalam-Islam, diakses 07 desember 2018, jam 06:39 WIB).

Pasar adalah sebuah mekanisme pertukaran produk baik berupa barang dan jasa yang alamiah dan telah berlangsung setelah peradaban awal manusia. Islam menempatkan pasar pada kedudukan yang paling penting dalam perekonomian. Praktik ekonomi pada masa Rasulullah SAW dan khulafaurrasyidin menunjukan adanya peranan pasar yang besar dalam pembentukan masyarakat Islam pada masa itu. Rasulullah SAW sangat menghargai harga yang di bentuk oleh mekanisme pasar sebagai harga yang adil. Beliau menolak adanya suatu intervensi harga seandainya perubahan harga terjadi karena mekanisme pasar yang wajar yaitu hanya karena pergeseran permintaan dan penawaran (Sutrisno, 2015: 7).

Pasar Dempo Permai Kota Pagar Alam merupakan salah satu pasar atau tempat sebagian besar pedagang mencari penghasilan dengan berdagang. Sistem yang dipakai para pedagang disana sesuai dengan kondisi yang ada. Maksud dari sesuai dengan kondisi yang ada yaitu mengikuti situasi ekonomi yang terjadi pada masyarakat saat itu.

Pasar Dempo Permai atau sering juga di sebut pasar tradisional adalah suatu tempat yang terdapat banyak penjual dan pembeli. Selain mengunakan sistem sesuai kondisi yang ada, pedagang juga mengunakan sistem tawar menawar atas suatu barang tertentu dengan menggunakan uang untuk memperolehnya.

Salah salah satu jenis dagangan yang ada di pasar Dempo Permai adalah pakaian. Pakaian merupakan salah satu kebutuhan pokok bagi manusia selain pangan dan papan. Pakaian merupakan alat penutup tubuh yang akan memberikan kepantasan, kenyamanan serta keamanan. Dalam kehidupan sehari-hari, kadang kita menyebutnya pakaian atau busana. Pakaian meliputi baju, blouse, kaos, rok, celana dan juga pakaian dalam 
(http://goklatenjualango.blogspot.com/2012/12/pengertian-atau-definisi-dan-fungsiserta-kegunaan-pakaian-dalam-kehidupan-masyarakat.html? $\mathrm{m}=1$, diakses tanggal 08 desember 2018, jam 06:25WIB).

Dengan demikian pedagang pakaian terletak di lantai dua dan berkisar 172 pedagang, sedangkan tukang penjahit beriksar 17 toko. Jadi dapat di simpulkan bahwa mayoritas pedagang yang ada di pasar Dempo Permai adalah pedagang pakaian.

Tabel 1.

Jenis Barang dan jumlah Pedagang di pasar Dempo Permai

\begin{tabular}{|c|c|c|}
\hline No & $\begin{array}{c}\text { Jenis Barang/Jasa yang diperjual } \\
\text { belikan }\end{array}$ & Jumlah Pedagang \\
\hline 1 & Pakaian & 172 \\
\hline 2 & Kosmetik & 10 \\
\hline 3 & Perak & 146 \\
\hline 4 & Sendal/sepatu/tas & 5 \\
\hline 5 & Alat Tulis & 20 \\
\hline 6 & Alat-alat Dapur & 17 \\
\hline 7 & Penjahit & 15 \\
\hline
\end{tabular}

Sumber: Data diolah dari Dinas PRINDAKOP Kota Pagar Alam 2019

Pedagang di pasar Dempo Permai mengunakan sistem tawar dengan harga yang tinggi (celling Price). Harga memang akan murah apabila pembeli bisa menawar sesuai keinginannya, tapi pada saat pembeli yang tidak bisa menawar maka harga yang tinggi akan di terima oleh pembeli tersebut. Terkadang kuliatas barang tidak sesuai dengan harga yang di tawarkan oleh pedagang, kualitas yang standar harganya tinggi, ini berarti terdapat unsur kedzaliman dalam penetapan harga di pasar Dempo Permai.

Berdasarkan pengamatan sementara, penetapan harga di pasar Dempo Permai belum menerapkan prinsip berdagang dalam Islam, di mana dalam pratiknya pedagang di pasar Dempo Permai menawarkan harga dengan tinggi, bahkan tiga kali lipat dari harga yang seharusnya di jual ke pembeli. Hal tersebut dapat merugikan pembeli dan tidak sesuai dengan prinsip berdagang dalam Islam yaitu bersikap kejujuran, kepercayaan, saling ridha, dan keadilan.

Pada pasar Dempo Permai los menjadi tempat saluran distribusi dimana produk bisa sampai kepada konsumen dan juga tempat bertemunya antara penjual dan pembeli. 
Los merupakan tempat-tempat atau lapak-lapak untuk para pedagang bejualan. Pedagang harus menyewa los/kios tersebut agar bisa berdagang di pasar Dempo Permai. Biaya sewa los/kios perpetak dari pemerintah tidak sampai Rp.4.000.000; akan tetapi pedagang banyak yang menyewa dari tangan kedua, maka harga sewa los/kios yang harus di bayar oleh pedagang 3 kali lipat bahkan lebih. Hal ini membuat para pedagang keberatan dengan harga sewa los/kios. Seharusnya ada intervensi dari pemerintah agar tidak ada yang terdzalimi antara pedagang dan pembeli.

Walaupun hal itu seakan menjadi kebiasaan antara pedagang dan konsumen, namun ada baiknya pelaku bisnis menerapkan konsep jual beli yang baik, jujur, tidak menimbun barang dan tidak merugikan orang lain. Penulis merasa lokasi inilah yang sesuai untuk dijadikan lokasi penelitian karena di pasar Dempo Permai terdapat para pedagang pakaian yang menjadi objek dalam penelitian ini.

Dari hasil penjelasan di atas maka masalah yang sering terjadi dalam hal penetapan suatu harga pakaian adalah tidak ada standarisasi dalam melakukan penjualan pakaian yang akan di jual dan belum ada ketegasan dari pemerintah mengenai sewa los/kios.Maka di dalam penelitian ini, peneliti ingin melakukan analisis tinjauan terhadap harga pakaian yang di terapkan di pasar Dempo Permai berdasarkan Hukum Islam agar tidak melanggar ketentuan syariah.

\section{PEMBAHASAN}

Berdasarkan observasi secara langsung dan memulai wawancara dengan para pedagang pakaian di pasar Dempo Permai, yaitu dengan para pedagang pakaian yang berjualan di pasar Dempo Permai, dengan demikian peneliti telah menghasilkan data. Dari observasi melalui wawancara, peneliti melihat secara langsung cara bagaimana para pedagang menentukan harga jual barang tersebut. Dari hasil wawancara, peneliti mengajukan pertanyaan yang berhubungan dengan penetapan harga pakai yang dilakukan oleh para pedagang pasar Dempo Permai dan alasan-alasan dalam menetapkan harga- harga dalam pengambilan atau memperoleh keuntungan. Selanjutnya setelah peneliti selesai mengumpulkan data-data yang berkaitan dengan pembahasan, peneliti akan mencoba membahas penetapan harga yang berlangsung di 
Ekonomica Sharia: Jurnal Pemikiran dan Pengembangan Ekonomi Syariah Volume 6 Nomor 1 Edisi Agustus $2020 \mid 39$

pasar Dempo Permai Kota Pagar Alam dan apakah penetapan harga tersebut sudah sesuai dengan hukum Islam.

Berdasarkan wawancara langsung dengan pedagang pakaian di pasar Dempo Permai mengenai penetapan harga pakaian yaitu dengan Ibu Suriati (38),

"Aku dide pernah matok harge sekian sehingge pembeli tu dide tau nawar, pembeli bebas nak nawar berape kina, selame aku dide rugi dide masalah. Kalu pembeli nawar harge di bawah harge modal, aku dide endak, nak pasti nginaki situasi ngahi kondisi, aku ngambek keuntungan $30 \%$ perbaju. Biasenye kami pedagang disini netapka harge tu ngitung biaye-biaye nak kami keluarka, empay kami ngambek keuntungan nak berape.

("Artinya: saya tidak pernah mematok harga sekian sehingga pembeli tidak bisa menawar, pembeli bebas menawar harga berapa saja. Yang jelas selama saya tidak rugi tidak ada masalah. Kalau pembeli menawar harga di bawah harga modal, baru saya tidak mau, yang jelas melihat situasi dan kondisi, keuntungan yang biasa saya ambil $30 \%$ perpotong baju. Biasanya kami menetapkan harga menghitung biaya- biaya yang di keluarkan, lalu baru mengambil keuntungan) (Suriati, Wawancara, Pagaralam, 26 April 2019)

Dari hasil wawancara tersebut dapat disimpulkan bahwa Ibu Suriati tidak pernah mematok harga, pembeli bebas menawar asal tidak membuat pedagang rugi dalam transaksi tawar menawar, ia mengambil keuntungan 30\% perpotong pakaian, mengenai mekanisme penetapan harga ia menghitung biaya-biaya yang dikeluarkan terlebih dahulu baru mengambil keuntungan.

Mekanisme penetapan harga yang di lakukan oleh pedagang pakaian di pasar Dempo Permai dari penghitungan biaya-biaya yang dikeluarkan yaitu biaya sewa los/kios, listrik, kebersihan, keamanan, transport, dan modal pengambilan barang. Setelah itu pedagang akan menetapkan keuntungan perpotong pakaian, akan tetapi keuntungan yang di dapat oleh pedagang dapat berubah-ubah karena tergantung sistem tawar menawar dengan pembeli dalam transaksi. Selanjutnya setelah pedagang dan pembeli bernegosiasi masalah harga maka akan menghasilkan penetapan harga pakaian tersebut. Dengan demikian maka mekanisme penetapan harga yang di lakukan pedagang pakaian pasar Dempo Permai dapat dilihat pada gambar 2 berikut: 


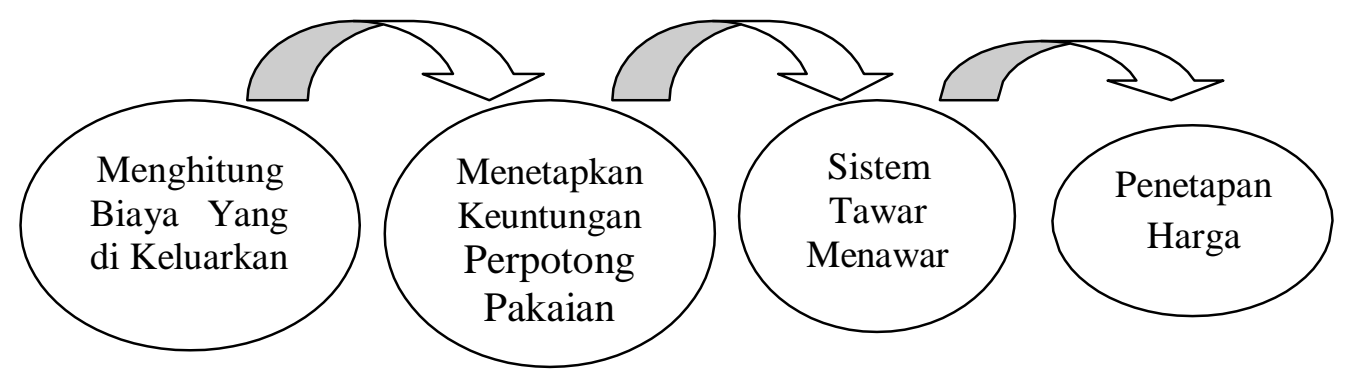

Gambar 2. Mekanisme Penentapan Harga Pedagang Pakaian di Pasar Dempo Permai Kota PagarAlam

Disini peneliti telah mengumpulkan data-data baik secara lisan maupun tertulis dengan ketiga teknik pengumpulan data yang digunakan, yang mana penelitian ini telah dilakukan sejak April s/d Mei 2019, sehingga diperoleh data-data yang cukup dan sesuai dengan masalah yang dilakukan dengan demikian hasil penelitian akan diuraikan sebagai beriku:

\section{Penetapan Harga di Pasar Dempo Permai Kota Pagar Alam}

Dari data harga pakaian di bawah ini dari hasil wawancara dan dokumentasi yang dilakukan oleh peneliti dengan pihak pendagang pakaian di pasar Dempo Permai Kota Pagar Alam terhadap harga pakaian. Dalam hal ini yang diwawancarai adalah Ibu Tati Halimah selaku salah satu pedagang pakaian di pasar Dempo Permai Kota Pagar Alam, sebagai wakil salah satu responden yang dipilih.

Berdasarkan hasil wawancara dengan Ibu Tati Halimah (32),

"Biasonyo penurunan hargo di sini berkisar Rp.20.0000; s/d Rp.90.000; perpotong baju/celano, tergantung tawar mzenawar dengan pembeli tula, kalo la di pucuk Rp.90.000; dak galak aku. Aku netapka hargo tu ngitung biayo-biayo yang dikeluarkan, baru aku ngambek keuntungan nak berapo."

"Artinya: biasanya penurunan harga disini berkisar Rp.20.000 s/d Rp.90.000 perpotong baju/celana, tergantung tawar menawar dengan pembeli, kalau sudah di atas Rp.90.000; tidak mau saya. Aku menetapkan harga menghitung biaya-biaya yang di keluarkan, baru mengambil keuntungan" (Tati Halimah, Wawancara, Pagaralam, 26 April 2019).

Menurut Ibu Tati Halimah selaku pedagang pakaian di pasar Dempo Permai menuturkan bahwa penurunan harga tawar pakaian di pasar dempo permai berkisar 
Ekonomica Sharia: Jurnal Pemikiran dan Pengembangan Ekonomi Syariah Volume 6 Nomor 1 Edisi Agustus 2020 | 41

Rp.20.000.00 s/d Rp.90.000.00 setiap harga pakaian barang yang di perjual belikan. Tergantung dengan sistem tawar menawar pada saat transaksi dan terkait permintaan dan penawaran pada mekanisme pasar itu sendiri. Dalam menetapkan harga ia menghitung biaya-biaya yang di keluarkan baru berapa mau mengambil keuntunga. Pendapat ini juga di benarkan oleh Ibu Nursanti (29) selaku pedagang pakaian di pasar Dempo Permai.

Dengan wawancara yang lebih lanjut, maka peneliti mengambil kesimpulan bahwa penjual pakaian dipasar Dempo Permai Pagar Alam tidak ingin penurunan harga tawar barang setiap potong harga pakaian di atas Rp.90.000, karena menurut mereka harga jual tersebut tidak bisa menutupi harga beli mereka dari distributor karena hal ini terkait biaya- biaya yang dikeluarkan, seperti biaya pengiriman barang dan biaya-biaya lain yang dikeluarkan. Umumnya para pedagang pakaian ingin memperoleh keuntungan walaupun sedikit dari setiap harga potong pakaian.

Dari semua penjelasan responden pedagang pakaian di pasar Dempo Permai, mengharapkan semua barang dagang yang akan diperjual belikan harus memperoleh keuntungan dari harga setiap potongya. Dari setiap keuntungan yang diperoleh sebagian besar mengunakan sistem celling price (harga tinggi). Dalam artian mereka menggunakan sistem tawar-menawar sesuai dengan penawaran dan permintaan yang ada. Mereka mengunakan harga tertinggi terdahulu, sehingga terjalinlah bernegosiasi antara pedagang dan pembeli.

Berdasarkan hasil wawancara dan observasi langsung dilapangan dengan para pedagang pakaian di pasra Dempo Permai, mengenai penetapan harga pakaian, maka disinila peneliti mendapatkan beberapa keterangan mengenai masalah harga, yang kemudian menjadi dasar bagi peneliti untuk menganalisis beberapa harga yang sebenarnya yang berlaku di pasar Dempo Permai, dan berapa keuntungan yang diperoleh para pedagang dari setiap harga potongan pakaian yang di jualnya. Harga ini mulai berlaku dari harga dasar sampai dengan harga jual setiap potongan pakaian tersebut. Disini peneliti mengambil harga pakaian sebagai contoh harga dari setiap potongan pakaian.

Berdasarkan hasil wawancara langsung, pedagang pakaian Pasar Dempo Permai dengan Ibu Desti (31), 
"Hampir seluruh pedagang disini ngambek baju ape celane di tanah abang" ("Artinya: mayoritas pedagang mengambil barang baju atau celana dari tanah abang".) (Desti, Wawancara, Pagaralam, 27 April 2019).

Dikarenakan mayoritas pedagang pakaian mengambil barang dari tanah abang, maka harga dasar setiap potong pakaian dari semua pedagang pakaian bisa dibilang sama. Setiap pakaian mempunyai kualitas dan harga tertentu, disini peneliti cuma mengambil jenis pakaian yang bermerek standar dan berkualitas standar, sebagaimana yang umunya di jual para pedagang yang ada di pasar Dempo Permai Kota Pagar Alam.

Tabel 3.

Daftar Nama dan Harga Setiap Jenis Pakaian di Pasar Dempo Permai Kota Pagar Alam untuk kebutuhan Perempuan

\begin{tabular}{|c|c|c|c|c|}
\hline No & Jenis-Jenis Pakaian & $\begin{array}{l}\text { Harga } \\
\text { Dasar }\end{array}$ & $\begin{array}{c}\text { Harga } \\
\text { Jual }\end{array}$ & $\begin{array}{l}\text { Keuntungan yang } \\
\text { diharapkan }\end{array}$ \\
\hline 1 & $\begin{array}{l}\text { Baju, untuk: } \\
\text { - Dewasa } \\
\text { - Anak-anak }\end{array}$ & $\begin{array}{l}\text { Rp. } 45.000 \\
\text { Rp. } 25.000\end{array}$ & $\begin{array}{l}\text { Rp.67.500 } \\
\text { Rp.37.500 }\end{array}$ & $\begin{array}{l}\text { Rp. } 22.500 \\
\text { Rp. } 12.500\end{array}$ \\
\hline 2 & $\begin{array}{l}\text { Celana pendek/panjang, untuk: } \\
\text {-Dewasa } \\
\text {-Anak-anak }\end{array}$ & $\begin{array}{l}\text { Rp. } 50.000 \\
\text { Rp. } 30.000\end{array}$ & $\begin{array}{l}\text { Rp.75.000 } \\
\text { Rp.45.000 }\end{array}$ & $\begin{array}{l}\text { Rp. } 25.000 \\
\text { Rp. } 15.000\end{array}$ \\
\hline 3 & $\begin{array}{l}\text { Baju Muslimah, untuk: } \\
\text {-Dewasa } \\
\text {-Anak-anak }\end{array}$ & $\begin{array}{l}\text { Rp. } 120.000 \\
\text { Rp.65.000 }\end{array}$ & $\begin{array}{l}\text { Rp. } 180.000 \\
\text { Rp. } 97.500\end{array}$ & $\begin{array}{l}\text { Rp.60.000 } \\
\text { Rp.32.500 }\end{array}$ \\
\hline 4 & $\begin{array}{l}\text { Jilbab biasa: untuk, } \\
\text {-Dewasa } \\
\text {-Anak-anak }\end{array}$ & $\begin{array}{l}\text { Rp. } 20.000 \\
\text { Rp. } 15.000\end{array}$ & $\begin{array}{l}\text { Rp. } 30.000 \\
\text { Rp. } 22.500\end{array}$ & $\begin{array}{l}\text { Rp.10.000 } \\
\text { Rp.7.500 }\end{array}$ \\
\hline
\end{tabular}

Sumber: Olah data (wawancara lansung terhadap pedagang pakaian di pasar Dempo Permai sejak bulan April s/d Mei 2019)

Tabel 4.

Daftar Nama dan Harga Setiap Jenis Pakaian di Pasar Dempo Permai Kota Pagar Alam untuk kebutuhan

Laki-laki

\begin{tabular}{|c|c|c|c|c|}
\hline No & Jenis-Jenis Pakaian & $\begin{array}{l}\text { Harga } \\
\text { Dasar }\end{array}$ & $\begin{array}{c}\text { Harga } \\
\text { Jual }\end{array}$ & $\begin{array}{l}\text { Keuntungan yang } \\
\text { diharapkan }\end{array}$ \\
\hline 1 & $\begin{array}{l}\text { Baju, kaos untuk: } \\
\text { - Dewasa } \\
\text { - Anak-anak }\end{array}$ & $\begin{array}{l}\text { Rp. } 45.000 \\
\text { Rp.25.000 }\end{array}$ & $\begin{array}{l}\text { Rp.67.500 } \\
\text { Rp.37.500 }\end{array}$ & $\begin{array}{l}\text { Rp. } 22.500 \\
\text { Rp. } 12.500\end{array}$ \\
\hline 2 & $\begin{array}{l}\text { Celana pendek/panjang, untuk: } \\
\text {-Dewasa } \\
\text {-Anak-anak }\end{array}$ & $\begin{array}{l}\text { Rp.70.000 } \\
\text { Rp.50.000 }\end{array}$ & $\begin{array}{l}\text { Rp.105.000 } \\
\text { Rp.75.000 }\end{array}$ & $\begin{array}{l}\text { Rp.35.000 } \\
\text { Rp.25.000 }\end{array}$ \\
\hline
\end{tabular}


Ekonomica Sharia: Jurnal Pemikiran dan Pengembangan Ekonomi Syariah Volume 6 Nomor 1 Edisi Agustus 2020

\begin{tabular}{|c|l|c|c|c|}
\hline 3 & Baju Muslimah, untuk: & & & \\
& -Dewasa & Rp.70.000 & Rp.105.000 & Rp.35.000 \\
& -Anak-anak & Rp.60.000 & Rp.90.000 & Rp.30.000 \\
\hline
\end{tabular}

Sumber: Olah data (wawancara lansung terhadap pedagang pakaian di pasar Dempo Permai sejak bulan April s/d Mei 2019)

Dari tabel 3 dan tabel 4 dapat disimpulkan, mengenai harga bisa berubah sesuai saat terjadinya sistem tawar-menawar di saat proses jual beli terjadi, dimana para pedagang pakaian bisa juga memperoleh keuntungan besar bahkan terkadang juga bisa rugi, tergantung stok pakaian yang tersedia. Tabel 3 dan 4 sebagai pedoman dari hasil survei yang berkenaan dengan harga.

Untuk penetapan harga yang maksimum tergantung pada saat sistem tawar menawar antara penjual dan pembeli. Berdasarkan pernyataan Ibu Tuti (35) dan Ibu Sukira (29),

"Untuk harge mamksimum itu dide terbatas, kami nawarka harge tinggi kudai, kele tu ade tawar menawar sandi pembeli, nak jelas eg kami mempertahankan modal ngahi keuntungan nak kami inginka. Merate di pasar dempo permai ni ngambek keuntungan tu $20 \%$ s/d $50 \%$ per baju ape celane."

("Artinya: untuk harge maksimum itu tidak ada batasnya, kami menawarkan harga tinggi terlebih dahulu, nanti ada tawar menawar dari pembeli, yang jelas kami memertahankan modal dan keuntungan yang kami inginkan. Kebanyakan di pasar Dempo Permai ini mengambil keuntungan 20\% s/d 50\% per baju atau celana" (Tuti, Sukira, Wawancara, Pagaralam, 26 April 2019)

Berdasarkan observasi yang telah dilakukan selama proses penelitian ini berlangsung dapat disimpulkan, bahwa sistem yang digunakan pedagang pasar Dempo Permai yaitu menawarkan dengan harga yang tinggi dulu (celling Price). Tergantung bagaimana sistem penawaran dan permintaan dalam dunia pasar itu sendiri. Hal ini berlaku dengan ketentuan bahwa harga ditentukan oleh pasar itu sendiri.

Pelaku pasar mempunyai tujuan yang utama dalam melakukan sebuah transaksi, yaitu mencapai ridha Allah SWT demi mewujudkan kemaslahatan hidup bersama disamping kesejahteraan individu. Untuk mencapai suatu ridha Allah SWT, maka manusia harus melakukan semua pekerjaan didasarkan pada keridhaan Allah SWT yang diwujudkan dari tindakan sesuai yang diajarkan oleh agama Islam. Dalam hal ini, berarti 
transaksi yang dilakukan oleh produsen dan konsumen harus sesuai dengan hukum Islam.

Oleh sebab itu Islam tidak memisahkan antara ekonomi dengan akhlak, berbeda dengan falsafah kapitalisme yang menjadikan keuntungan materi sebagai tujuan utama pemberi motivasi terbesar untuk melakukan kegiatan perekonomian yang tidak banyak ikatan-ikatan seperti Islam, sehingga mereka tidak melarang mencari keuntungan dengan jalan riba atau menimbun barang-barang yang sangat dibutuhkan masyarakat atau menjual yang mendatangkan keuntungan bagi dirinya saja (Kamalia, 2017: 29)

Prinsip dasar perdagangan menurut Abdul Ghopur (2017: 110-111) adalah sebagai berikut:

1) Kejujuran (honesty) kejujuran adalah suatu yang harus dilakukan oleh seorang pedagang dalam melakukan aktivitas perdagangan. Tidak boleh berbohong, tidak boleh menipu, tidak berkhianat, tidak ingkar janji dan hal-hal yang sejenis dengannya. Seperti yang dilakukan oleh Ibu Reni Suryani (25),

"selame aku bejualan disini aku belum pernah rugi, anye dapat keuntungan tu agak kecik, karne aku nawarka barang tu dengan harge nak standar ngahi aku dide naik ka harge pada saat aghi-aghi tertentu, karne ame aku naikka harge barang pelanggan ku pacak lengit, aku nawarka harge barang tu sesuai ngahi kualitas barang eg tu"

("artinya: selama saya berdagang di sini, saya belum pernah sampai mengalami kerugian, hanya saja saya medapat keuntungan yang sedikit. Karena saya mewarkan harga yang standar dan tidak menaikan harga pada saat hari-hari tertentu, karena kalau saya menaikan harga pelanggan saya bisa hilang dan saya selalu menawarkan harga barang sesuai dengan kualitasnya ") (Reni Suryani, Wawancara, Pagaralam, 26 April 2019)

Berdasarkan hasil wawancara langsung dengan Ibu Reni Suryani, ia menawarkan harga berang sesuai dengan kualitas barang tersebut, ia menawarkan harga standar dan tidak menaikan harga pada saat hari-hari tertentu. Ini berarti Ibu Reni Suryani (25) sudah mengunakan prinsip berdagang dalam Islam. Hal ini juda di perkuat oleh Ibnu Taimiyah mengenai laba yang adil, berikut penjelasannya

"Seseorang yang memperoleh barang untuk mendapatkan keuntungan dengan memperdagangkannya di kemudian hari diperbolehkan melakukan hal tersebut. Akan tetapi, ia tidak boleh mengenakan keuntungan yang tinggi 
dari pada yang berlaku terhadap orang-orang miskin, dan ia seharusnya tidak menaikan harga terhadap mereka yang sedang membutuhkan (dharurah)" (Farma, 2018: 186).

Dalam hal ini, Ibnu Taimiyah melarang penjualan barang kepada orang miskin dengan cara mengekploitasi keadaan mereka. Seorang penjual harus tetap menjual barangnya dengan harga yang berlaku secara umum, jika pembelinya adalah orang yang sangat membutuhkan.

2) Kepercayaan (trust) kepercayaan antar pelaku perdagangan, yakni penjual dan pembeli sangatlah penting, sebab tanpa adanya kepercayaan dari kedua belah pihak, maka akan sulit terjadi kesepakatan perdagangan pada pembeli.

3) Saling ridha (rela) antara pihak yang terkait (penjual dan pembeli) perdagangan yang dianjurkan dalam Islam adalah perdagangan yang menguntungkan dan membawa berkah bagi kedua belah pihak. Keduanya harus saling rela tanpa adanya paksaan, tidak ada satu pihak yang merasa terdzalimi. Berdasarkan wawancara secara langsung dengan Ibu Tati Halimah (32), ia mengatakan,

"sistem transaksi di pasar Dempo Permai ni makai sistem tawar menawar, dalam transaksi tawar menawar tu berarti la rela same rela antara pedagang ngahi pembeli, karne pembeli nawar harge barang sekian pedagang setuju ngahi harge itu, itu berarti la rela sama rela"

("artinya: sistem transaksi di pasar Dempo Permai memakai sistem tawar menawar, dalam transaksi tawar menawar tersebut sudah terjadi rela sama rela antara pedagang dengan pembeli, karena apabila pembeli menawar dengan harga tertentu dan pedagangpun setuju, maka sudah terjadi rela sama rela") (Tati Halimah, wawancara, Pagaralam 26 April 2019).

Transaksi jual beli di Pasar Dempo Permai yaitu dengan sistem tawar-menawar, dimana pedagang dan pembeli melakukan diskusi untuk menetapkan harga suatu barang, apabila pedagang dan pembeli sama-sama setuju dengan hasil penetapan harga barang maka transaksi tersebut sudah terjadi rela sama rela.

4) Tidak mendurhakai Allah SWT manusia diwajibkan bekerja untuk memenuhi kebutuhan hidupnya. Akan tetapi dalam bekerja, manusia tidak boleh melalaikan kewajiban-kewaajiban beribadah kepada Allah SWT. Dalam hal ini Ibu Nurpala (36) mengatakan, 
46 M. Agus Maryanto, et.al, Analisis Tinjauan Hukum Islam Terhadap Pedagang....

"selame aku jualan alhamdulilah aku dide nipuka pembeli, mengenai harge aku selalu nawarka harge sesuai ngahi kualitas barang eg tu, ame barang eg alap ku kicek ka alap, anye ame barang eg standar ku kicek ka standar"

("Artinya: Selama saya berjualan alhamdulillah saya tidak menipu pembeli, mengenai harga saya selalu menawarkan harga sesuai dengan kualitas barang tersebut, kalu bagus saya katakan bagus, kalau standar saya katakan standar") (Nurpala, Wawancara, Pagaralam, 26 April 2019).

Berdasarkan hasil wawancara tersebut, pedagang tidak menipu pembeli pada saat transaksi, apabila kualitas barangnya bagus mereka akan mengatakan bagus, dan sebaliknya. Mengenai harga yang tinggi yang di terime oleh pembeli, itu tergantung sistem tawar menawar pada saat transaksi terjadi. Pendapat ini juga di benarkan oleh pedagang lainnya yaitu Tati Halimah (32), Nupala (36), Reni Suryani (25), Serli (42), Suriati (38), Sukira (29), Tuti (35), Mariana (45), Fatma (32) dan Kastoni (41).

5) Prinsip keadilan banyak penjelasan-penjelasan dalam Al-Qur'an yang menekankan pentingnya menegakkan prinsip keadilan, terutama dalam hal ekonomi. Dengan menegakkan prinsip keadilan ini, maka akan berpengaruh pada lingkungannya. Berdasarkan wawancara Ibu Tati Halimah (32), mengatakan,

"Keadilan dalam bedagang ni dimano barang nak di jual sepadan dengan harga nak di tawarka di tempat dan waktu yang sama, penjual dan pembeli tu ketemu secara langsung" (keadilan dalam berdagang ini dimana barang yang dijual sepadan dengan harga yang di tawarkan di tempat dan waktu yang sama, penjual dan pembeli bertemu secara langsung") (Tati Halimah, Wawancara, Pagaralam, 26 April 2019).

Berdasarkan hasil wawancara langung prinsip keadilan bahwa barang yang jual sepadan dengan harga yang di tawarkan di tempat waktu yang sama, penjual dan pembeli bertemu secara langsung. Hal ini juga di perkuat oleh Ibnu Taimiyah, ia mengatakan,

"Nilai harga di mana orang-orang menjual barangnya dan diterima secara umum sebagai hal yang sepadan dengan barang yang dijual ataupun barang-barnag yang sejenis lainnya di tempat dan waktu yang sama" (Farma, 2018: 185).

\section{Metode Penetapan Harga di Pasar Dempo Permai}

Berdasarkan beberapa pernyataan yang telah diwawancarai dari beberapa orang selaku penjual pakaian di pasar Dempo Permai, salah satunya Ibu Jana (35), 
"Saya tidak megunakan metode perhitungan untuk menetapkan harga pakaian seperti yang telah di kenal dalam dunia ekonomi maupun metode yang berhubungan dengan dunia bisnis yang secara umum, tetapi disini saya memperhitungkan bagaimana saya tidak mengalami rugi dan modal saya tidak berkurang dalm proses penjualan, kembali lagi bagaimana sistem penawaran dan permintaan dalam dunia pasar itu sendiri, kalau tidak merasa rugi maka proses jual belinya akan terjadi” (Jana, Kastoni, Wawancara, Pagaralam, 27 April 2019)

Dalam pernyataan tersebut, maka peneliti berkesimpulan bahwa jika di tinjau dari metode penetapan harga dalam ekonomi, mereka memperhitungkan biaya-biaya yang di keluarkan lalu menetapkan berapa keuntungan yang akan di ambil setiap potong pakaian. Pendapat ini juga di benarkan oleh Bapak Kastoni (41) selaku pedagang pakaian.

Di dalam penetapan harga, terdapat berbagai macam metode. Metode mana yang digunakan tergantung pada tujuan penetapan harga yang ingin dicapai. Penetapan harga biasanya dilakukan dengan menambah besarnya biaya produksi bagi usaha manufaktur dan diatas modal atas barang dagangan bagi usaha dagang. Metode penetapan harga dikelompokan menjadi empat macam berdasarkan basisnya, yaitu sebagai berikut:

a. Metode Penetapan Harga Berbasis Permintaan

Metode ini lebih menekankan pada faktor-faktor yang mempengaruhi selera dan keinginan pelanggan sendiri dan didasarkan pada berbagai pertimbangan, diantaranya yaitu daya beli, kemauan pelanggan untuk membeli, posisi suatu produk dalam gaya hidup pelanggan, manfaat yang diberikan produk tersebut kepada pelanggan, dan sifat persaingan non harga.

b. Metode Penetapan Harga Berbasis Biaya

Dalam metode ini faktor penentu harga yang utama adalah aspek penawaran atau biaya, bukan aspek permintaan. Harga ditentukan berdasarkan biaya produksi dan pemasaran yang ditambah dengan jumlah tertentu sehingga dapat menutupi biaya-biaya langsung, biaya tidak langsung dan laba.

c. Metode Penetapan Harga Berbasis Persaingan

Metode ini berdasarkan pada pertimbangan biaya, permintaan dan laba. Harga dapat diterapkan atas dasar persaingan, yaitu apa yang dilakukan pesaing.

d. Metode penetapan Harga Laba 
Metode ini berusaha menyeimbangkan pendapatan dan biaya dalam penetapan harganya.

Berdasarkan penjelasan diatas bahwa penetapan harga yang dilakukan pedagang pasar Dempo Permai Kota Pagaralam adalah penetapan harga berdasarkan metode penetapan harga berbasis persaingan, diperjelas oleh Ibu Nani (32)

"Dalam menetapkan harga saya mengunakan cara menghitung total biaya yang saya keluarkan kemudian di tambah dengan keuntungan yang saya inginkan" (Nani, Suka, Wawancara, Pagaralam, 27 April 2019)

Mereka menetapkan dengan cara menghitung total biaya yang mereka keluarkan. Selanjutnya ditambah biaya transport dan biaya lainnya kemudian ditambah dengan margin keuntungan atau laba yang diingkinkan, maka itu harga jual produk. Dalam menetapkan harga pedagang juga melihat situasi pedagang lainnya. Pendapat ini juga di benarkan oleh pedagang lainnya yaitu Suka (36), Tati Halimah (32), Nupala (36), Nani (32), Kastoni (41), Suriati (38), Desti (31), Nursanti (29), Reni Suryani (25), dan Sukira (29).

Laba adalah keuntungan atau hasil dari penjualan. Menurut Al- Mushlih dan AshShawi, laba adalah selisih lebih hasil penjualan dari harga pokok dan biaya operasi. Kalangan ekonomi mendefinisikannya sebagai, selisih antara total penjualan dengan total biaya, total penjualan, yakni harga barang yang dijual, dan total biaya yang operasioanl adalah seluruh biaya yang dikeluarkan dalam penjualan, yeng terlihat dan tersembunyi (Mahdyyah, 2016: 73).

Ibnu Al-Arabi, "setiap mu'awadhah (barter) merupakan perdagangan terhadap apa pun bentuk barang penggantinya, si pelaku barter hanya menginginkan kualitas (sifat) barang atau jumlahnya, sedangakan laba adalah kelebihan yang diperoleh oleh seseorang atas nilai barang pengganti." (Mahdyyah, 2016: 73).

Sesuai dengan teori yang dibahas sebelumnya mengenai penetapan harga di pasar Dempo Permai Kota Pagar Alam, maka disini peneliti mencoba menghubungkan dengan teori Ibnu Taimiyah, setelah melakukan wawancara dan observasi secara langsung dengan pedagang pakaian di pasar Dempo Permai, berdasarkan pernyataan dilapangan, umunya pedagang pakaian di pasar Dempo Permai dalam menetapkan 
Ekonomica Sharia: Jurnal Pemikiran dan Pengembangan Ekonomi Syariah Volume 6 Nomor 1 Edisi Agustus 2020 | 49

harga, dapat dikatakan sudah sesuai dengan teori Ibnu Taimiyah dan Ibnu Qayyim dalam konsep penetapan harga.

Ibnu Taimiyah dengan tegas mengatakan bahwa harga ditentukan oleh kekuatan permintaan dan penawaran tergantung bagaimana dalam mekanisme pasar itu sendiri, harga bisa naik turun karena penurunan barang yang tersedia atau peningkatan jumlah konsumen. Menurut Ibu Mariana salah satu pedagang pakaian di pasar dempo permai mengatakan bahwa kenaikan harga terjadi pada saat menjelang lebaran, karena banyak pembeli pada saat menjelang lebaran, ia sendiri juga menaikan harga pada saat itu, karena untuk menutupi pendapatan pada saat musim sepi. Pendapat ini juga dibenarkan oleh pedagang pakaian lainnya yaitu Ibu Fatma (32). (Mariana, Fatma, Wawancara, Pagaralam, 26 April 2019)

Ibnu Taimiyah mencatat beberapa faktor yang mempengaruhi permintaan serta kosekuensinya terhadap harga, yaitu:

1) Keinginan masyarakat (raghbah) terhadap berbagai jenis barang yang berbeda dan selalu berubah-ubah. Perubahan ini sesuai dengan langka atau tindaknya barang-barang yang diminta. Semakin sedikit jumlah suatu barang yang tersedia akan semakin diminati oleh masyarakat. Berdasarkan hasil wawancara dengan pedagang di pasar dempo permai, pada saat barang sedikit pedagang pakaian di pasar Pempo Permai akan banyak menjual barang tersebut dengan harga tawar yang cukup tinggi.

2) Jumlah para peminat (tullab) terhadap suatu barang. Jika jumlah masyarakat yang menginginkan suatu barang semakin banyak, harga barang tersebut semakin meningkat, dan begitu pula sebaliknya. Berdasarkan Banyaknya minat masyarakat dalam mengingainkan suatu barang juga berpengaruh terhadapa harga di pasar Dempo Permai, pedagang akan menaikan harga pada saat itu.

3) Lemah atau kuatnya kebutuhan terhadap suatu barang serta besar atau kecilnya tingkat dan ukuran kebutuhan. Apabila kebutuhan besar dan kuat, harga akan naik. Sebaliknya, jika kebutuhan kecil dan lemah, harga akan turun. Seperti yang terjadi di pasar Dempo Permai pada saat harihari tertentu membuat para pedagang menaikan harga dengan cukup 
$50 \mid$ M. Agus Maryanto, et.al, Analisis Tinjauan Hukum Islam Terhadap Pedagang.... tinggi.

4) Kualitas pembeli, jika pembeli adalah seorang yang kaya dan terpercaya dalam membayar utang, harga yang diberikan lebih rendah. Sebaliknya harga yang diberikan lebih tinggi jika pembeli adalah seseorang yang sedang bangkrut, suka mengulu-ulur pembayaran utang serta mengingkari utang. Pada pasar Dempo Permai hal yang seperti ini terjadi pada saat pembeli mengenal baik pedang atau kerabat pedagang, hal ini berpengaruh terhadap harga, apabila pedagang mengenal baik pembeli maka harga akan turun dan sebaliknya.

5) Jenis uang yang digunakan dalam transaksi, harga akan lebih rendah jika pembayaran dilakukan dengan mengunakan uang yang umum di pakai (naqd ra'ij) dari pada uang yang jarang dipakai. Berdasarkan hasil wawancara beberapa pedagang pakaian di pasar Dempo Permai hal yang seperti ini jarang terjadi, kerana uang yang digunakan dalam transaksi jual beli memakai uang rupiah.

6) Tujuan transaksi yang meghendaki adanya kepemilikan resiprokal diantara kedua belah pihak. Harga suatu barang yang telah tersedia di pasaran lebih rendah dari pada harga suatu barang yang belum ada dipasaran. Begitu pula halnya harga akan lebih rendah jika pembayaran dilakukan secara tunai dari pada pembayaran dilakukan secara tidak langsung. Pada pasar Dempo Permai apabila barang yang dijual belum ada stoknya atau di pesan terlebih dahulu dan pembayaran dilakukan tidak langsung atau di cicil maka harga yang berlaku akan mengalami kenaikan, karena ada resiko-resiko yang harus di tanggung oleh pedagang.

7) Besar kecilnya biaya yang harus dikeluarkan oleh perodusen atau penjual. Semakin besar biaya yang dibutuhkan oleh produsen atau penjual untuk menghasilkan atau memperoleh barang akan semakin tinggi pula harga yang diberikan, dan begitu pula sebaliknya. Pedagang pasar Dempo Permai Kota Pagar Alam menetapkan harga dengan memperhitungkan biaya-biaya yang di keluarkan. 
Ekonomica Sharia: Jurnal Pemikiran dan Pengembangan Ekonomi Syariah Volume 6 Nomor 1 Edisi Agustus $2020 \mid 51$

Ibnu Taimiyah juga menjelaskan ketika terjadi ketidakadilan harga maka pemerintah boleh melakukan intervensi demi menjaga kemaslahatan ummat bahkan pemrintah boleh memaksa penjual untuk menjual dengan standar harga atau harga yang setara, ketika terjadi sebuah ketidakadilanyang merajalela sebagaimana diungkap dalam Al-Hisbah fi Al-Islam sebagai berikut,

Dan wajib apabila tidak mungkin untuk menghilangkan semua kedzaliman maka menghilangkan yang mungkin saja, maka menetapkan harga yang setara ini adalah suatu kewajiban artinya memberikan kosekuensi mereka untuk menjual dan membeli hanya dengan harga yang setara (Putra, 2011: 45-46).

Dalam wawancara mengenai harga pada Ibu Tati Halimah (32), ia mengatakan bahwa

"aku nyewo kios ni dari tangan kedua bukan dari perintah, hargo aku nyewo ini Rp.20.000.000/tahun, sebenarnyo lebih tinggi bekali-kali lipat dari hargo permerintah. Tapi katek pilihan lain, laju nyewo disini, kareno katek lagi tempat yang kosong dari pemerintah, itu la pasalnyo aku nawarke dengan hargo yang tinggi untuk nutupi biayo-biayo yang dikeluarka. Aku ngambek keuntungan tu $50 \%$ per potong pakaian, kalo pedagang yang nyewo kios dari pemerintah dio ngambek untung 20\% s/d 30\%". ("Artinya: saya menyewa kios dari tangan kedua bukan dari perintah, harga saya menyewa Rp.20.000.000/tahun, sebenarnyo lebih tinggi berkali-kali lipat dari harga pemerintah. Tapi saya tidak ada pilihan lain menyewa tempat ini, karena tidak ada lagi tempat yang kosong dari pemerintah, mangkanya saya menawarkan dengan harga yang tinggi untuk menutupi biaya-biaya yang di keluarkan. Saya mengambil keuntungan $50 \%$ per potong pakaian, kalau pedagang yang menyewa dari pemerintah mereka mengambil keuntungan $20 \% \mathrm{~s} / \mathrm{d} 30 \%$.)

Hasil wawancara tersebut menjelaskan bahwa kios/los yang di sewanya pada saat ini di sewa dari tanggan kedua bukan dari pemerintah, harga sewa los/kios yang ia tempati pada saat ini Rp.20.000.000/tahun, lebih tinggi dari pada harga yang di tetapkan oleh pemerintah. Oleh karena itu ia menawarkan harga pakaian dengan harga yang tinggi dan mengambil keuntungan 50\%, untuk menutupi biaya-biaya yang di keluarkan selain sewa los/kios. Sedangkan pedagang yang menyewa los/kios dari pemeritah menawarkan harga yang standar dan mengambil keuntungan $20 \%$ s/d $30 \%$. Pendapat ini 
juga dibenarkan oleh Arif (28), Serli (42), Sukira (29), dan Fatma (32). (Tati Halimah, Wawancara, Pagaralam, 26 April 2019).

Dapat disimpulkan bahwa harus ada intervensi dari pemerintah mengenai retribusi sewa los/kios, dan pemerintah harus lebih tegas dalam mengatur sewa los/kios agar tidak ada yang mengambil keuntungan lebih tinggi dalam harga sewa. Harga sewa los/kios di pasar Dempo Permai juga berpengaruh terhadap penetapan harga pada pedagang pakaian.

Berdasarkan hasil wawancara langsung dengan Bapak Hendriansyah (32),

"untuk masalah sewa pihak kami sudah melakukan tinjauan langsung ke pasar, dan memang benar bahwa ada oknum-oknum yang mengabil keuntungan dalam menyewakan los/kios tersebut, dan Pak Wali Kota pun sudah turun langsung ke lapangan. Beliau telah menghimbau kepada pedagang untuk menyewa los/kios langsung ke pemerintah jangan lagi ke oknum-oknum tersebut. sekarang kami sedang membuat surat kontrak untuk pedagang untuk meminimalisir oknum-oknum tersebut. Butuh waktu yang juga untuk mestabilkan kembali sewa los/kios tersebut, karena tidak mudah, dan jika masih ada oknum-oknum yang masih mengambil keuntung sewa ada tidak tegas dari pemeritah."

Dalam hasil wawancara dengan Bapak Hendriansyah menjelaskan bahwa pihak pengelola pasar itu sendiri sudah turun langsung kelapangan, bahkan Bapak Wali Kota pun sudah meninjau langsung ke pedagang untuk mengetahui apakah benar ada oknumoknum yang mengambil keuntungan dalam sewa los/kios, dan menghimbau kepada pedagang agar menyewa langsung ke pemerintah. Ada tidakan tegas dari pemrintah jika masih ada oknum-oknum yang masih mengambil keuntungan sewa di pasar Dempo Permai.

Masalah intervensi penentuan hargajuga di perkuat oleh Ibnu Qayyim, ia mengatakan bahwa penentuan harga harus di serahkan kepada kekuatan pasar, yakni kekuatan permintaan dan penawaran, jika terjadi ketidaksempurnaan pasar (Distorsi), misalnya monopoli dia merekomendasikan permerintah untuk memperbaiki harga pasar (Rozalinda, 2017: 165).

Dalam konsep Islam, penentuan harga dilakukan oleh kekuatan- kekuatan pasar, yakni kekuatan permintaan dan penawaran. Pertemuan permintaan dan penawaran 
Ekonomica Sharia: Jurnal Pemikiran dan Pengembangan Ekonomi Syariah Volume 6 Nomor 1 Edisi Agustus $2020 \mid 53$

tersebut haruslah terjadi rela sama rela, dalam artian tidak ada pihak yang terpaksa untuk melakukan transaksi pasa tingkat harga tertentu (Sutrisno, 2017: 59-60).

Bila transaksi sudah sesuai aturan kenaikan harga yang terjadi merupakan kehendak Allah SWT. Hal tersebut menunjukan sifat pasar yang impersonal. Dibedakan pula dua faktor penyebab pergeseran kurva penawaran dan permintaan, yaitu tekanan pasar yang otomatis dan perbuatan yang melaggar hukum dari penjual, misalnya penipuan atau penimbunan. (Sutrisno, 2017: 59-60).

Berdasarkan hasil wawancara dengan pedagang mengenai kualitas barang yang di jualkan, mereka mengatakan bahwa pada saat transaksi jual beli berlangsung selalu mengatakan kualitas barang yang dijualnya bagus atau tidak, kualitas barang tersebut berpengaruh terhadap harga jual, tergantung sistem tawar menawar pada saat transaksi.

Dengan demikian pedagang pakaian pasar Dempo Permai Kota Pagaralam juga tidak melakukan tadlis. Tadlis disini dalam artian tindakan seorang peniaga yang sengaja mencampur barang yang berkualitas baik dengan barang yang sama tetapi berkualitas buruk demi untuk memberatkan timbangan atau untuk mendapatkan keuntungan yang lebih banyak.

Al-Qur'an dengan tegas telah melarang semua transaksi bisnis yang mengandung unsur penipuan dalam segala bentuk terhadap pihak lain. Seperti dijelaskan dalam QS. Al-An'aam: 152

Artinya: dan janganlah kamu dekati harta anak yatim, kecuali dengan cara yang lebih bermanfaat, hingga sampai ia dewasa. Dan sempurnakanlah takaran dan timbangan dengan adil. Kami tidak memikulkan beban kepada sesorang melainkan sekedar kesanggupannya. dan apabila kamu berkata, Maka hendaklah kamu Berlaku adil, Kendatipun ia adalah kerabatmu, dan penuhilah janji Allah SWT. yang demikian itu diperintahkan Allah SWT kepadamu agar kamu ingat (Kementerian Agama, 1938: 204).

Penjelasan dari ayat diatas, sudah sangat jelas sekali, bahwa sangat dilarang melakukan tadlis dalam hal jual beli terutam dalam penentuan harga. Maka hal tersebut dapat diklarifikasikan dalam beberapa pernyataan kalau bagus mereka katakan bagus, tapi kalau itu kualiatasnya buruk mereka katakan itu buruk sesuai dengan motif dan jenis pakaian yang dijual dalam setiap potongnya. 
Peranan harga menjadi sangat penting untuk diperhatikan mengingat harga merupakan salah satu penyebab laku tidaknya produk yang ditawarkan baik itu tawar menawar dal hal pakaian. Hasil wawancara yang menganalisis tentang harga dinyatakan leh para responden, Ibu Tati Halimah adalah perwakilan dari beberapa pedagang yang diwawancarai, menurutnya ada tiga kemungkinan mereka menetapkan harga, ia menyatakan,

Tabel 5.

Rekapitulasi Data dalam Persentase Tingkat Harga dan Tingkat Keuntungan yang diperoleh para Pedagang Pakaian dipasar Dempo Permai Kota Pagaralam

\begin{tabular}{|c|c|c|}
\hline No & Jenis Tngkat Harga & Persentase Penawaran dari Tiap Jenis \\
\hline 1. & Harga Standar & $20 \% \mathrm{~s} / \mathrm{d} 30 \%$ \\
\hline 2. & Harga Menengah & $30 \% \mathrm{~s} / \mathrm{d} 40 \%$ \\
\hline 3. & Harga Tinggi & $40 \% \mathrm{~s} / \mathrm{d} 50 \%$ \\
\hline
\end{tabular}

Sumber: Olah data (wawancara lansung terhadap pedagang pakaian di pasar Dempo Permai sejak bulan April s/d Mei 2019)

Dari tabel diatas dapat dijelaskan bahwa harga tersebut tergantung dengan model atau motif dari pakaian yang diperjual belikan, seperti yang telah dibahas pada bagian sebelumnya, mereka mengambil keuntungan dari harga yang sebenarnya paling minim $20 \%$ dari setiap potong pakaian, dan paling maksimum berkisar $50 \%$ itu juga tergantung bagaimana permintaan dan penawaran dalam mekanisme pasar itu sendiri.

Tetapi kebanyakan dari mereka lebih menggunakan harga tinggi dalam menentukan harga, tergantung situasi pasar itu sendiri, sesuai dengan permintaan dan penawarannya. Hal ini juga di tegaskan oleh Bapak Serli selaku penjual pakaian dipasar Dempo Permai, apabila harga yang kami tawarkan mahal maka kami akan memberikan barang yang asli bukan tipuan dari motifnya sesuai dengan kualitas yang terbaik sesuai dengan harga tersebut. Sehingga tidak ada unsur mendzolimi bagi para pembeli (Serli, Wawancara, Pagaralam, 27 April 2019).

Berdasarkan pernyataan yang diberikan oleh Ibu Tati Halimah berkaitan dengan mereka memperoleh keuntungan dalam hal penetapan harga secara langsung di peroleh dari para pembeli sesuai dengan keadaan pasar atau dalam istilah sesuai dengan 
Ekonomica Sharia: Jurnal Pemikiran dan Pengembangan Ekonomi Syariah Volume 6 Nomor 1 Edisi Agustus 2020 | 55

permintaan dan penawaran yang ada. Maka dapat disimpulkan bahwa harga satuan dari tiap potong pakaian sudah sesuai dengan hukum Islam.

Harga yang di yang ditetapkan oleh para pedagang pakaian dipasar Dempo Permai dan tujuan menetapkan harga tersebut, maka dapat disimpulkan dari beberapa pertanyaan responden, dalam masalah harga yang diberlakukan oleh para pedagang pakaian di Pasar Dempo Permai adalah harga yang sudah sesuai, karena mereka juga menghitungkan beberapa cost yang dikeluarkan dalam menentukan modal atas jual beli pakaian, juga mempertimbangkan dalam menentukan harga sesuai keadaan pasar yang ada, dan tujuan mereka menentukan harga tersebut untuk memperoleh biaya-biaya yang sudah dikeluarkan dari modal awal.

Dalam hal demikian dari pendapat tersebut terkait dengan pengertian harga di dalam Islam. Ibnu Taimiyah mendefinisikan harga yang adil atau harga yang setara adalah harga yang berlaku ketika masyarakat yang menjual barang-barang degangannya dan secara umum dapat diterima sebagai suatu yang setara bagi barang-barang tersebut.

Ibnu Taimiyah juga menjelaskan bahwa harga yang setara adalah harga yang terbentuk dari kekuatan permintaan dan penawaran, harga bisa naik turun karena penurunan barang yang tersedia atau peningkatan jumlah konsumen.

Berdasarkan harga yang adil, dalam pandangan Ibnu Taimiyah, adil bagi para pedagang berarti barang-barang dagangan mereka tidak dipaksa untuk dijual pada tingkat harga yang dapat menghilangkan keuntungan normal mereka, setiap individu mempunyai hak pada apa yang mereka miliki. Tidak ada seorangpun yang bisa mengambilnya, baik sebagian maupun seluruhnya, tanpa izin dan persetujuan.

Harga tidak dapat dikatakan adil apabila harga tersebut terlalu rendah sehingga penjual tidak dapat menutupi biaya-biaya yang dikeluarkannya dan tidak boleh terlalu tinggi karena akan memberatkan konsumen, harga yang adil adalah harga yang dapat menutupi semua biaya operasional produsen atau penjual dengan tingkat laba tertentu serta tidak merugikan konsumen. Dalam konsep Islam harga yang adil sangatlah berperan penting dalam menentukan penawaran dan permintaan supaya tidak ada pihak yang merasa terpaksa dalam melakukan transaksi pada tingkat tertentu. Ketentuan ini berdasarkan dalam Al-Qur'an surat An-Nisaa ayat 29: 
56 M. Agus Maryanto, et.al, Analisis Tinjauan Hukum Islam Terhadap Pedagang....

Artinya: Hai orang-orang yang beriman, janganlah kamu saling memakan harta sesamamu dengan jalan yang batil, kecuali dengan jalan perniagaan (jual beli) yang berlaku dengan suka sama-suka di antara kamu. Dan janganlah kamu membunuh dirimu (saudaramu). Sesungguhnya Allah SWT adalah Maha Penyayang kepadamu (Kementerian Agama, 1938: 112).

Ayat di atas menerangkan hukum transaksi secara umum, lebih khusus kepada transaksi perdagangan, bisnis jual beli. Dalam ayat ini Allah SWT mengharamkan orang beriman untuk memakan, memanfaatkan, menggunakan, dan segala bentuk transaksi lainnya harta orang lain dengan jalan yang batil, yaitu yang tidak dibenarkan oleh syariat. Kita boleh melakukan transaksi terhadap harta orang lain dengan jalan perdagangan saling ridha dan saling ihklas. Dalam ayat ini Allah SWT juga melarang untuk bunuh diri, baik membunuh diri sendiri maupun saling bunuh dan Allah SWT menerangkan semua ini sebagai wujud dari kasih sayang-Nya, karena Allah SWT itu Maha Kasih Sayang kepada kita (Tafsir Surat AN-Nisa' (4): Ayat 29,http://mkitasolo.blogspot.com/2011/12/tafsir-surat- nisa-4-ayat-29.html?m=1, diakses pada tanggal 07 April 2019, Pukul 11:45).

Dalam ayat diatas sangat menganjurkan selaku pembeli dan penjual dalam masalah perniagaan yang dilakukan oleh kedua belah pihak, dimana menekankan harus adanya kerelaan kedua belah pihak dalam melakukan perniagaan. Walaupun kerelaan adalah sesuatu yang tersembunyi dilubuk hati, tetapi tindikator atau tanda-tandanya dapat dilihat. Ijab dan Kabul atau yang dikenal dalam adat kebiasaan sebagai serah terima adalah bentuk-bentuk yang digunakan hukum untuk menentukan kerelaan.

Berdasarkan pernyataan ayat diatas ada hubungannya dengan hasil responden yang diwawancarai secara langsung dengan penjual pakaian di pasar Dempo Permai dapat disimpulkan, maka yang dilakukan oleh pedagang pakaian di pasar Dempo Permai dalam penetapan harga dan tujuan yang relevan sesuai dengan hukum Islam, tergantung dengan permintaan dan penawaran dari harga setiap potongan pakaian mereka juga mengunakan asas suka sama suka terhadap transaksi jual beli pakaian tersebut. Mereka juga melakukan perhitungan biaya atau ongkos pengambilan barang yang dikeluarkan dalam biaya transportasi atau biaya pengiriman barang tersebut dan biaya-biaya lainnya. 
Ekonomica Sharia: Jurnal Pemikiran dan Pengembangan Ekonomi Syariah Volume 6 Nomor 1 Edisi Agustus 2020 | 57

Menurut responden yang diwawancarai secara langsung dapat disimpulkan bahwa keuntungan yang diperoleh dari setiap potongan harga pakaian adalah berkisar kurang lebih $20 \%$ s/d $50 \%$ dari modal perpotong pakaian, itu pun keuntungan tersebut untuk kelangsungan dari permodalan setiap potongan pakaian untuk pengambilan lebih lanjut.

Dalam konsep Islam tidak memiliki batasan yang jelas tentang laba atau keuntungan. Sehingga, pedagang bebas menentukan laba yang diiginkan dari suatu barang. Islam tidak memberikan standarisasi pasti terkait pengambilan laba dalam jual beli. Dengan demikian, sepantasnya bagi seorang muslim untuk tidak mendzalimi sesama muslim yang lain dengan mengambil keuntungan terlalu besar. Islam tidak melarang untuk mengambil keuntungan, namun dalam batas wajar.

Dari penjelasan diatas dapat disimpulkan bahwa di dalam Islam keuntungan tidak di tentukan. Dalam hal ini Ibnu Taimiyah menjelaskan laba yang adil bagi pedagang berarti barang-barang dagangan mereka tidak dipaksa untuk dijual pada tingkat harga yang dapat menghilangkan keuntungan normal mereka.

Ketika berbicara masalah laba atau keuntungan, disini Ibnu Khaldun juga menjelaskan bahwa keuntungan yang wajar akan mendorong tumbuhnya perdagangan. Sedangkan jika harga-harga dari jenis barang manapun tetap rendah pedagang kehilangang modalnya, hal yang sama hancurnya penghidupan para pedagang berlaku bila harga terlalu tinggi, yang memberikan laba dan penghidupan bagi orang-orang adalah harga.

Berdasarkan penjelasan di atas mengenai keuntungan dalam Islam, maka keuntungan yang di dapat oleh para pedagang pakaian di pasar Dempo Permai Kota Pagaralam masih dikatagorikan dengan harga yang wajar, karena pada dasarnya para pedagang pakaian di pasar tersebut memperhitungkan biaya-biaya yang dikeluarkan dalam penetapan harga.

Dengan demikian dalam Islam tidak ada pembatasan dalam menentukan suatu keuntungan dari setiap harga, semuanya itu tergantung pada aturan mekanisme pasar itu sendiri yang berkaitan dengan penawaran dan permintaan tanpa menghilangkan sikap santun dan moral dalam bersikap. Untuk itu dalam pedagang pakaian di pasar Dempo Permai, dapat disimpulkan dalam hal memperoleh laba. Keuntungan yang mereka peroleh tidak lain untuk mengsungkan usaha meraka dalam bejualan pakaian 


\section{8}

M. Agus Maryanto, et.al, Analisis Tinjauan Hukum Islam Terhadap Pedagang....

untuk mengingat dan mengibangi biaya atau ongkos pengiriman barag serta biaya-biaya yang dikeluarkan lainnya.

\section{SIMPULAN}

Berdasarkan penelitian dan pembahasan ini, maka dapat di simpulkan bahwa:

1. Pedagang pakaian pasar Dempo Permai Kota Pagar Alam menerapkan metode penetapan berbasis biaya. Dimana Mekanisme penetapan harga yang di lakukan oleh pedagang pakaian di pasar Dempo Permai dari penghitungan biaya-biaya yang dikeluarkan yaitu biaya sewa los/kios, listrik, kebersihan, keamanan, transport, dan modal pengambilan barang. Setelah itu pedagang akan menetapkan keuntungan perpotong pakaian, akan tetapi keuntungan yang di dapat oleh pedagang dapat berubah-ubah karena tergantung sistem tawar menawar dengan pembeli dalam transaksi. Selanjutnya setelah pedagang dan pembeli bernegosiasi masalah harga maka akan menghasilkan penetapan harga pakaian tersebut.. Sistem yang digunakan para pedagang pasar Dempo Permai yaitu menawarkan dengan harga yang tinggi dulu (celling Price).Tergantung bagaimana sistem penawaran dan permintaan dalam dunia pasar itu sendiri. Ini artinya bahwa hukum ekonomi menurut teori Ibnu Taimiyah harga ditentukan oleh pasar itu sendiri atau mekanisme pasar itu sendiri.

2. Konsep penetapan harga yang adil dalam hukum Islam sesuai dengan ajaran AlQura'an dan Sunnah, maka harus mewujudkan jual beli yang terjadi dengan cara rela sama rela. Dalam konsep Islam penentuan harga harus dilakukan oleh kekuatan permintaan dan penawaran. Metode penetapan harga yang dilakukan oleh pedagang pasar Dempo Permai Kota Pagar Alam menggunakan metode penetapan harga berbasis persaingan, sesuai catatan Ibnu Taimiyah dalam faktor yang mempengaruhi permintaan serta kosekuensi terhadap harga. Kemudian pedagang pasar Dempo Permai mengambil keuntungan tidak melebihi 50\% dari harga dasar, tergantung tawar menawar pada saat terjadinya transaksi. Hal ini sesuai dengan ajaran Islam tidak melarang berapa mengambil keuntungan. Tetapi jangan sampai terlalu tinggi mengambil keuntungan sehingga dapat merugikan pihak pembeli yang lebih tinggi. Peran pemerintah sangat di harapkan untuk menstabilkan harga 
Ekonomica Sharia: Jurnal Pemikiran dan Pengembangan Ekonomi Syariah Volume 6 Nomor 1 Edisi Agustus 2020 | 59 di pasar Dempo Permai.

3. Disamping itu juga penulis menyarankan agar penelitian ini tidak sampai disini saja, melainkan penulis berharap ada penelitian selanjutnya agar hasil penelitian ini dapat lebih optimal. 


\section{DAFTAR PUSTAKA}

Aravik, Havis. 2016. Ekonomi Islam: Konsep, Teori, dan Aplikasi serta Pandangan Pemikir Ekonomi Islam dari Abu Ubaid sampai Al-Maududi. Malang: Empat Dua.

Aseng Yopinbeska, http://www.scribd.com/document/367759210/Makalah-EkonomiIslam-Konsep-Pasar-Dalam-Islam, diakses 07 desember 2018, jam 06:39 WIB

Darma surya Putra, Pemikiran Ibnu Taimiyah Tentang Standar Harga dalam Jual Beli, (UIN Sultan Syarif Kasim: Riua 2011

Farma Junia. 2018. Mekanisme Pasar dan Regulasi Harga Telaah Atas Pemikiran Ibnu Taimiyah, Jurnal Studi Islam

Ghofur Abdul. 2017. Pengantar Ekonomi Syariah, Depok: Rajawali Pers

http://banksyariahindo.wordpress.com/2011/10/23/tafsir-al-baqarah-ayat-275/, diakses pada tanggal 06 April 2019, Pukul 19:43 WIB

http://goklatenjualango.blogspot.com/2012/12/pengertian-atau-definisi-dan-fungsiserta-kegunaan-pakaian-dalam-kehidupan-masyarakat.html? $\mathrm{m}=1, \quad$ diakses tanggal 08 desember 2018, jam 06:25WIB

Huda Nurul.2008. Ekonomi Makro Islam, Jakarta: Kencana

Kamalia, Mekanisme Penetapan Harga Dalam Pandangan Ekonomi Islam (Studi KasusPada Pedagang Asongan di Pelabuhan Sungai Duku Pekanbaru, Riau: UIN Sultan Syarif Kasim.

Kementerian Agama RI.1938. Tafsir Quran Karim, Jakarta: P.T Hidakarya Agung

Mahdyyah Almaulal, Penetapan Harga di Kalangan Pedagang Buah di Pasar Peterongan Jombang Tinjauan Hukum Islam, (UIN Maulana Malik Ibrahim: Malang 2016),

Rozalinda. 2017. Ekonomi Islam, Depok: Rajawali Pers

Saifullah Muhammad. 2011. Artikel Etika Bisnis dalam Praktik Binis Rasulullah, Semarang: IAIN Walisongo

Sutrisno Tri. 2015. Tinjauan Ekonomi Islam Terhadap Penetapan Harga Pakaian Jadi Di Pasar KM 5 Kota Palembang, Palembang: UIN Raden Fatah

Tafsir Surat AN-Nisa' (4): Ayat 29,http://mkitasolo.blogspot.com/2011/12/tafsir-suratnisa-4-ayat-29.html?m=1, diakses pada tanggal 07 April 2019, Pukul 11:45

Zamzam, H. F., \& Aravik, H. 2020. Etika Bisnis Islam Seni Berbisnis Keberkahan. Deepublish. 